\title{
Characterization of 35 novel microsatellite DNA markers from the duck (Anas platyrhynchos) genome and cross-amplification in other birds
}

\author{
Yinhua HUANG ${ }^{\mathrm{a} *}$, Jianfeng $\mathrm{TU}^{\mathrm{a}, \mathrm{b}}$, Xuebo $\mathrm{CHENG}^{\mathrm{a}}$, Bo TANG ${ }^{\mathrm{a}}$, \\ Xiaoxiang $\mathrm{HU}^{\mathrm{a}}$, Zhaoliang $\mathrm{LIU}^{\mathrm{a}}$, Jidong FENG ${ }^{\mathrm{a}}$, Yankun LOU ${ }^{\mathrm{a}}$, \\ Li LIN ${ }^{\mathrm{a}}$, Ke XU' ${ }^{\mathrm{a}}$, Yulong $\mathrm{ZHAO}^{\mathrm{a}}$, Ning $\mathrm{LI}^{\mathrm{a} *}$ \\ ${ }^{\text {a }}$ State Key Laboratory for Agrobiotechnology, China Agricultural University, Yuanmingyuan, \\ West Road 2, Beijing 100094, China \\ ${ }^{\mathrm{b}}$ College of Animal Science and Technology, Jiangxi Agricultural University, \\ Nanchang 300045, China
}

(Received 11 January 2005; accepted 10 February 2005)

\begin{abstract}
In order to study duck microsatellites, we constructed a library enriched for (CA)n, (CAG)n, (GCC)n and (TTTC)n. A total of 35 pairs of primers from these microsatellites were developed and used to detect polymorphisms in 31 unrelated Peking ducks. Twenty-eight loci were polymorphic and seven loci were monomorphic. A total of 117 alleles were observed from these polymorphic microsatellite markers, which ranged from 2 to 14 with an average of 4.18 per locus. The frequencies of the 117 alleles ranged from 0.02 to 0.98 . The highest heterozygosity (0.97) was observed at the CAUD019 microsatellite locus and the lowest heterozygosity (0.04) at the CAUD008 locus, and 11 loci had heterozygosities greater than 0.50 (46.43\%). The polymorphism information content (PIC) of 28 loci ranged from 0.04 to 0.88 with an average of 0.42 . All the above markers were used to screen the polymorphism in other bird species. Two markers produced specific monomorphic products with the chicken DNA. Fourteen markers generated specific fragments with the goose DNA: 5 were polymorphic and 9 were monomorphic. But no specific product was detected with the peacock DNA. Based on sequence comparisons of the flanking sequence and repeat, we conclude that 2 chicken loci and 14 goose loci were true homologous loci of the duck loci. The microsatellite markers identified and characterized in the present study will contribute to the genetic map, quantitative traits mapping, and phylogenetic analysis in the duck and goose.
\end{abstract}

duck / microsatellite marker / enriched library / polymorphism / cross-species amplification

* Corresponding author: ninglbau@ public3.bta.net.cn 


\section{INTRODUCTION}

Molecular genetic maps will provide insight into the genome organization and chromosomal localization of cloned genes, and also provide a framework for the identification and location of major genes associated with economically important traits [7]. In recent years, rapid advances have been made in the development of molecular genetic maps. High-density linkage maps are now available for many farm animals, such as cattle, pigs, and goats. In contrast, mapping studies in avian species are much less advanced except in the chicken. In order to construct saturated genetic maps for more bird species, the isolation of many polymorphic genetic markers, particularly microsatellite markers is an eventual pre-requisite.

Microsatellites or simple sequence repeats (SSR) are tandem repeated motifs of 1-6 bases found in all prokaryotic and eukaryotic genomes, and are present both in coding and noncoding regions. Because of their high polymorphism, they have been extensively used in forensics, genetic mapping, population genetics, evolutionary studies and investigation of social systems [3-5,13].

Although microsatellites are very informative genetic markers, the need for prior sequence information to produce locus-specific primer sets is a major limitation. Traditionally, microsatellite loci have been isolated from partial genomic libraries (selected for small insert size) from the species of interest, and several thousands of clones screened through colony hybridization with repeatcontaining probes [30]. Although relatively simple, especially for microsatellite rich genomes, this approach can be extremely tedious and inefficient for species with low microsatellite frequencies, such as avian species. Several procedures for microsatellite library enrichment have been developed to improve the efficiency of microsatellite isolation. They can be classified according to the capture technique: (1) streptavidin-coated magnetic beads; (2) microsatellite probes attached to small nylon membranes; (3) other not frequently used procedures, such as the use of the dut ung strain of E.coli or magnetic capture of phage DNA [32].

The Peking duck, the most common type of duck bred for meat, was exported to the United States and Britain from China in the last century. Many meat type ducks have originated from this breed. Ducks, which are different from the chicken (order Galliformes), belong to the order Anseriformes. According to paleontological data, the main radiation of modern ducks took place during the Miocene, 5-23 million years ago [26]. Ducks together with the ostrich, emu, peacock, turkey, quail, and other birds play a major role in studies on bird evolution. Up to now, most available data concerning ducks have come from heritabilities and genetic correlations of some 
traits $[2,12,33,39]$ and epidemiology $[11,20,21]$. Most available molecular data have come from evolution studies based on the analysis of mitochondrial DNA sequence $[6,8,14,15,22,34]$. However, information about genetic markers in the duck is limited [3,23,24, 29,35], and therefore we isolated and characterized 35 novel microsatellite markers for this species. In the hopes of developing universal microsatellite primers for birds, 35 duck microsatellite markers were used to identify the homologous loci in the chicken, peacock and goose.

\section{MATERIALS AND METHODS}

\subsection{Construction of the microsatellite-enriched library}

A microsatellite-enriched partial genomic library was constructed using total genomic DNA extracted from blood collected from the wing vein of one female Peking duck (Anas platyrhynchos). The library was enriched for (AC)n, (ACG)n, (GCC)n and (TTTC)n by following a combination of modified procedures according to Kanpdal et al. [16], Fischer et al. [10], Takashi et al. [36] and Tang [37]. Genomic DNA fragments ranging in size from 300-1000 bp were recovered using the Geneclean kit (Q BIO GENE) after digestion with HaeIII and RsaI (Promega). The recovered fragments $(1 \mu \mathrm{g})$ were ligated to an adaptor $(5 \mu \mathrm{g}$, consisting of a 21-mer: 5'CTCTTGCTTGAATTCGGACTA3' and a phosphorylated 25-mer: 5'pTAGTCCGAATTCAAGCAAGAGCACA3') with T4 DNA ligase. The fragments with adaptors were denatured at $98{ }^{\circ} \mathrm{C}$ for $10 \mathrm{~min}$, then, quick chilled in an ice bath. At the same time, 450 pmol (CA)n, 250 pmol(CAG)n, 250 pmol (GCC)n, 250 pmol (TTTC)n biotinylated oligonucleotide were attached to $900 \mathrm{ng}$ of streptavidin magnetic beads (Biolabs) in $200 \mu \mathrm{L} 5 \times \mathrm{SSC}$ at room temperature for 1 hour. The excess unbound probe was removed twice with $200 \mu \mathrm{L} 5 \times \mathrm{SSC}$. Then, the streptavidin magnetic beads were re-suspended in $20 \times$ SSC (final concentration $6 \times$ SSC) and hybridized with $100 \mu \mathrm{L}$ predenatured fragments at $65{ }^{\circ} \mathrm{C}$ overnight. The beads were then washed three times at low stringency conditions (room temperature in $2 \times \mathrm{SSC}$, $1 \% \mathrm{SDS}, 5 \mathrm{~min}$ each), six times at high stringency conditions (3 times in $1 \times \mathrm{SSC}$ at room temperature, and 3 times in $1 \times \mathrm{SSC}$ at $65^{\circ} \mathrm{C}, 5 \mathrm{~min}$ each) and once in cold low salt buffer $(0.15 \mathrm{M} \mathrm{NaCl}, 20 \mathrm{mM}$ Tris- $\mathrm{HCl}(\mathrm{pH} 7.5), 1 \mathrm{mM}$ EDTA) for $2 \mathrm{~min}$. Finally, the beads were eluted as single-stranded fragments using an elution buffer (10 mM Tris- $\mathrm{HCl}$ ( $\mathrm{pH} 7.5), 1 \mathrm{mM}$ EDTA). The final elution served as a template for PCR (the 21-mer oligonucleotide as the 
unique primer, $20-25$ cycles of $94{ }^{\circ} \mathrm{C}$ for $1 \mathrm{~min}, 60{ }^{\circ} \mathrm{C}$ for $1 \mathrm{~min}$, and $72{ }^{\circ} \mathrm{C}$ for $1 \mathrm{~min}$ ) in order to obtain double-stranded fragments. The PCR products were purified, ligated to pMD 18-T vector (Takara) and transformed into E.coli DH5 $\alpha$ competent cells to produce a microsatellite-enriched library.

\subsection{Sequencing of positive clones and designing of primers}

Plasmids, extracted from clones of the microsatellite-enriched library, were sequenced with the BigDye Terminator Kit on ABI PRISM 377 DNA sequencers (Perkin-Elmer, USA). Oligo6.0 and the Primer3 web site [28] were used to design PCR primers. The length of the primers ranged from 18 to $25 \mathrm{bp}$, and was designed to give PCR products ranging from 100 to $400 \mathrm{bp}$. One primer in each pair was labeled with either 6-FAM or HEX fluorescent dye (Augct Biotechnology Co. Ltd).

\subsection{Birds}

Thirty-one unrelated individuals from a breeding population (15 males and 16 females) were sampled from Gold Star Duck Production Ltd (Peking). A total of 30 individuals were used for cross-species amplification with 35 duckspecific microsatellite primers: 10 chickens (3 Silkies, 3 Beijing Fatty chickens and 4 Brown Shell Layers) from the Chicken Breeding Farm of China Agricultural University; 10 Peacocks (3 Blue-Peacocks, 3 White-Peacocks and 4 Green-Peacocks) from Yingjieli Co., Ltd, Guangdong province; 10 geese (2 Rhin, 2 Landaise, $3 \mathrm{Zi}$ and 3 Xiayan) from Fangzheng Agro-Industry Co., Ltd, Jilin province. A routine phenol/chloroform extraction method was used to extract and purify the duck, chicken, peacock and goose genomic DNA. The DNA was qualified using agarose gel electrophoresis. The DNA concentration was estimated by comparison with molecular markers.

\subsection{Optimization of mutiplex PCR and muti-run}

The annealing temperature of the microsatellite primers was determined using an Authorized Thermal Cycler (Eppendorf). DNA amplification was performed in a total volume of $10 \mu \mathrm{L}$, with $40 \mathrm{ng}$ duck DNA, 50mM $\mathrm{KCl}, 1.5 \mathrm{mM} \mathrm{MgCl}_{2}, 10 \mathrm{mM}$ Tris. $\mathrm{HCl}$ ( $\mathrm{pH} 8.3$ ), $1 \mathrm{mM}$ Tetramethylammoniumchloride (TMAC), $0.1 \%$ Triton X-100, 0.01\% gelatin, 200mM dNTP, 0.2 to 2 pmol of each primer and $2.5 \mathrm{U}$ Taq polymerase. The PCR reaction conditions 
were denaturing for $5 \mathrm{~min}$ at $94{ }^{\circ} \mathrm{C}$, followed by $94{ }^{\circ} \mathrm{C}$ for $40 \mathrm{~s}, 58 \pm 10{ }^{\circ} \mathrm{C}$ for $30 \mathrm{~s}$ or $1 \mathrm{~min}$, and $72{ }^{\circ} \mathrm{C}$ for $30 \mathrm{~s}$ or $1 \mathrm{~min}$, with a final $30 \mathrm{~min}$ elongation step at $72{ }^{\circ} \mathrm{C}$. PCR primer pairs with similar annealing temperatures and different amplification product sizes were combined in mutiplex PCR reactions. Primer pairs unsuitable for mutiplex PCR were used in independent reactions, however, the products could be run in the same lane (muti-run) of the gel if their sizes were sufficiently different ( $>60 \mathrm{bp}$ ).

\subsection{Cross-species amplification and sequence}

PCR parameters used for cross-species amplification were the same as in the duck except for annealing temperature. Initially, PCR was tested at the annealing temperature suggested for the duck. If the PCR product was not found on the $2 \%$ agarose gel, PCR was optimized using a 12-degree annealing temperature $\left( \pm 10^{\circ} \mathrm{C}\right)$ in an Authorized Thermal Cycler. Markers that generated specific products similar to the size fragments of the duck were selected for genotyping. These specific amplified products were sequenced with a reverse primer, or ligated to pMD 18-T vector and transformed into E.coli DH5 $\alpha$ competent cells, then sequenced with the universal primer (M13).

\subsection{Genotyping}

Mutiplex PCR products or independent PCR products were diluted by 10-70 times. A mixture of $1 \mu \mathrm{L}$ diluted PCR product, $12 \mu \mathrm{L}$ deoinized formadide (Amresco), and $0.2 \mu \mathrm{L}$ Genescan-350 $\mathrm{ROX}^{\mathrm{TM}}$ or Genescan-500 ROX ${ }^{\mathrm{TM}}$ (ABI) internal standard was run on a 3100 pop- $4^{\mathrm{TM}}$ (ABI) using a 3100 genetic analyzer (ABI). The fragment sizes of PCR products were analyzed using the Genescan 3.7 and Genemapper 1.1 software (ABI).

\subsection{Statistics}

Statistical evaluations of the microsatellite markers, including the allele frequency, observed heterozygosity, expected heterozygosity and polymorphism information content (PIC), were performed using the Popgene analysis software (Version 1.31) developed by Francis Yeh (ftp://ftp.microsoft.com/Softlib/ MSLFILES/HPGL.EXE). DNAman Version 5.2.2 was used to search for sequence homology among the duck, chicken and goose. 


\section{RESULTS}

\subsection{Characteristics of the microsatellite markers}

The characteristics of 35 novel microsatellite markers, including GenBank accession number, microsatellite repeat sequence, sequence of the PCR primers, the optimal annealing temperature for PCR, as well as the length of PCR products are shown in Table I.

The number of repeats in the microsatellites ranged from 6 to 52 with an average of 18.29/sequence (see Tab. I). Polymorphisms were detected in 31 unrelated individuals according to the conditions of the optimized mutiplex PCR and muti-run. Twenty-eight (80\%) of the 35 primer pairs exhibited sequence length polymorphisms. A total of 117 alleles were observed from these polymorphic microsatellite markers, and the number of alleles ranged from 2 to 14 with an average of 4.18 per microsatellite locus. The frequencies of the 117 alleles ranged from 0.04 to 0.98 (Tab. II). Twenty-three frequencies of the 117 alleles were higher than 0.5 (Tab. II). Among the polymorphic markers, the highest heterozygosity (0.97) was observed at CAUD019 and the lowest heterozygosity (0.04) at CAUD008 (Tab. II). A total of 11 loci had heterozygosities greater than 0.50 (39.29\%). The polymorphism information content (PIC) of 28 loci ranged from 0.04 to 0.88 . The percentage of the loci with a PIC greater than 0.50 was $32.14 \%$ (9), with a PIC between 0.25 and 0.5 was $50 \%$ (14), and with a PIC lower than 0.25 was $17.86 \%$ (5). Sequences of 35 duck microsatellites were submitted to GenBank (AY493246-AY493280). Seven markers that were monomorphic in the genotyped individuals, are also listed in Table I.

\subsection{Cross-species amplification}

Thirty-five duck-specific primers were employed to screen the homologous loci in the chicken, peacock and goose. Amplification products were obtained with 5 (14.29\%) markers in the chicken, with 4 (11.43\%) markers in the peacock, with $22(62.86 \%)$ markers in the goose. Amplified products with the sizes of the duck in each species were to investigate the polymorphism in 10 individuals. The characteristics of 16 homologous microsatellite markers, including GenBank accession number, repeat unit, sequence similarity between species, annealing temperature for PCR, as well as the length of the PCR products are shown in Table III. Homologous markers of CAUD016 and CAUD027 were detected in the chicken (CAUD-C016 and CAUD-C027) and goose (CAUD-G016 and CAUD-G027) respectively. All of them were 


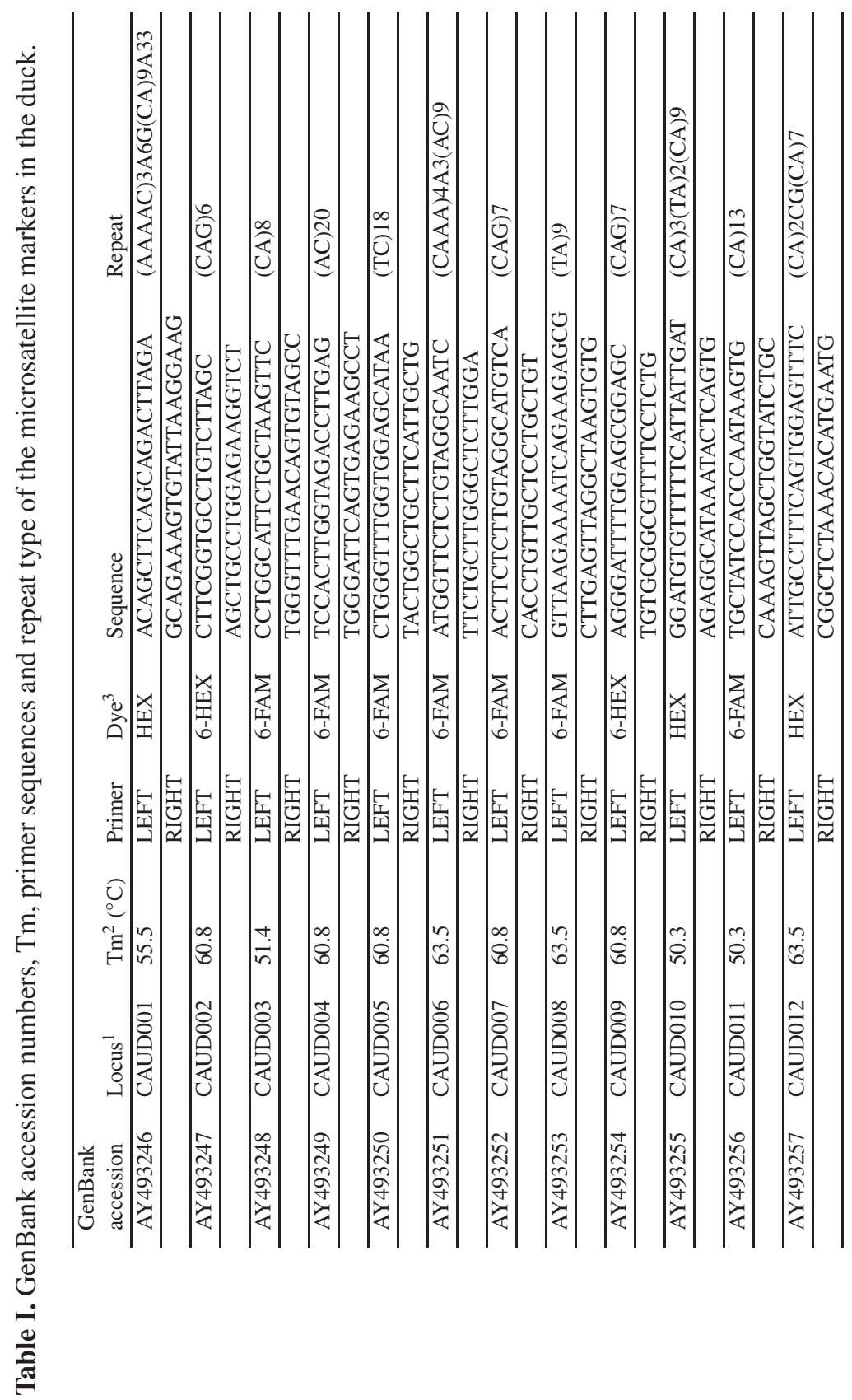









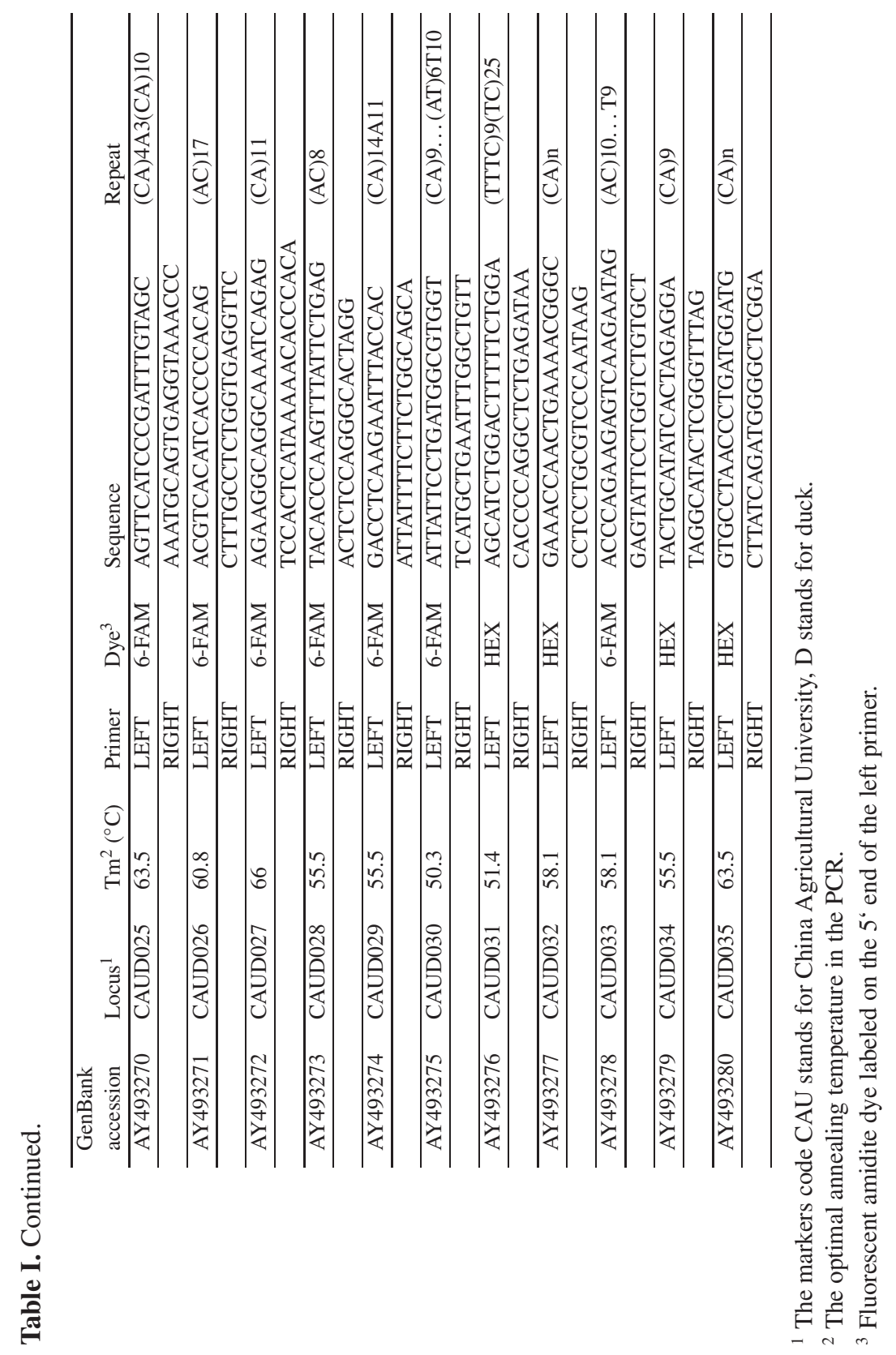


Table II. The characteristics of the novel microsatellite markers in the duck.

\begin{tabular}{|c|c|c|c|c|c|c|c|}
\hline Locus & Fragment & Allele No. & Obs_Ht ${ }^{1}$ & $\mathrm{PIC}^{2}$ & Allele & size & Frequency \\
\hline \multirow[t]{5}{*}{ CAUD001 } & $315-331$ & 5 & 0.68 & 0.51 & $\mathrm{~A}$ & 315 & 0.02 \\
\hline & & & & & B & 317 & 0.39 \\
\hline & & & & & $\mathrm{C}$ & 321 & 0.02 \\
\hline & & & & & $\mathrm{D}$ & 323 & 0.50 \\
\hline & & & & & $E$ & 331 & 0.08 \\
\hline CAUD002 & $188-188$ & 1 & 0.00 & 0.00 & A & 188 & 1.00 \\
\hline CAUD003 & $115-115$ & 1 & 0.00 & 0.00 & A & 115 & 1.00 \\
\hline \multirow[t]{5}{*}{ CAUD004 } & $199-221$ & 5 & 0.59 & 0.56 & $\mathrm{~A}$ & 199 & 0.02 \\
\hline & & & & & B & 201 & 0.19 \\
\hline & & & & & $\mathrm{C}$ & 209 & 0.55 \\
\hline & & & & & $\mathrm{D}$ & 211 & 0.03 \\
\hline & & & & & $\mathrm{E}$ & 221 & 0.21 \\
\hline \multirow[t]{5}{*}{ CAUD005 } & $250-284$ & 5 & 0.32 & 0.30 & A & 250 & 0.02 \\
\hline & & & & & B & 259 & 0.10 \\
\hline & & & & & $\mathrm{C}$ & 267 & 0.82 \\
\hline & & & & & $\mathrm{D}$ & 282 & 0.03 \\
\hline & & & & & $\mathrm{E}$ & 284 & 0.03 \\
\hline CAUD006 & $210-210$ & 1 & 0.00 & 0.00 & A & 210 & 1.00 \\
\hline CAUD007 & $108-108$ & 1 & 0.00 & 0.00 & A & 108 & 1.00 \\
\hline \multirow[t]{2}{*}{ CAUD008 } & $102-104$ & 2 & 0.04 & 0.10 & A & 102 & 0.06 \\
\hline & & & & & B & 104 & 0.94 \\
\hline CAUD009 & $127-127$ & 1 & 0.00 & 0.00 & $\mathrm{~A}$ & 127 & 1.00 \\
\hline \multirow[t]{3}{*}{ CAUD010 } & $112-116$ & 3 & 0.16 & 0.20 & $\mathrm{~A}$ & 112 & 0.05 \\
\hline & & & & & B & 114 & 0.89 \\
\hline & & & & & $\mathrm{C}$ & 116 & 0.06 \\
\hline \multirow[t]{4}{*}{ CAUD011 } & $121-140$ & 4 & 0.58 & 0.57 & $\mathrm{~A}$ & 121 & 0.02 \\
\hline & & & & & B & 127 & 0.23 \\
\hline & & & & & $\mathrm{C}$ & 131 & 0.27 \\
\hline & & & & & $\mathrm{D}$ & 140 & 0.48 \\
\hline \multirow[t]{2}{*}{ CAUD012 } & $202-204$ & 2 & 0.05 & 0.04 & A & 202 & 0.02 \\
\hline & & & & & B & 204 & 0.98 \\
\hline \multirow[t]{7}{*}{ CAUD013 } & $85-113$ & 7 & 0.68 & 0.63 & A & 85 & 0.10 \\
\hline & & & & & B & 91 & 0.24 \\
\hline & & & & & $\mathrm{C}$ & 95 & 0.10 \\
\hline & & & & & $\mathrm{D}$ & 105 & 0.02 \\
\hline & & & & & $\mathrm{E}$ & 107 & 0.50 \\
\hline & & & & & $\mathrm{F}$ & 111 & 0.03 \\
\hline & & & & & G & 113 & 0.02 \\
\hline \multirow[t]{2}{*}{ CAUD014 } & 113-117 & 2 & 0.42 & 0.32 & A & 113 & 0.73 \\
\hline & & & & & $\mathrm{B}$ & 117 & 0.27 \\
\hline \multirow[t]{2}{*}{ CAUD015 } & $118-122$ & 2 & 0.19 & 0.27 & A & 118 & 0.20 \\
\hline & & & & & B & 122 & 0.80 \\
\hline
\end{tabular}


Table II. Continued.

\begin{tabular}{|c|c|c|c|c|c|c|c|}
\hline Locus & Fragment & Allele No. & Obs_Ht ${ }^{1}$ & PIC $^{2}$ & Allele & size & Frequency \\
\hline \multirow[t]{5}{*}{ CAUD016 } & $189-217$ & 5 & 0.37 & 0.46 & A & 189 & 0.67 \\
\hline & & & & & B & 193 & 0.22 \\
\hline & & & & & $\mathrm{C}$ & 209 & 0.03 \\
\hline & & & & & $\mathrm{D}$ & 213 & 0.02 \\
\hline & & & & & E & 217 & 0.07 \\
\hline \multirow[t]{3}{*}{ CAUD017 } & $216-262$ & 3 & 0.25 & 0.16 & $\mathrm{~A}$ & 216 & 0.17 \\
\hline & & & & & B & 218 & 0.88 \\
\hline & & & & & $\mathrm{C}$ & 262 & 0.02 \\
\hline \multirow[t]{2}{*}{ CAUD018 } & $98-100$ & 2 & 0.37 & 0.30 & A & 98 & 0.75 \\
\hline & & & & & B & 100 & 0.25 \\
\hline \multirow[t]{13}{*}{ CAUD019 } & $132-213$ & 13 & 0.97 & 0.87 & $\mathrm{~A}$ & 132 & 0.08 \\
\hline & & & & & B & 136 & 0.10 \\
\hline & & & & & $\mathrm{C}$ & 140 & 0.02 \\
\hline & & & & & $\mathrm{D}$ & 145 & 0.06 \\
\hline & & & & & $E$ & 149 & 0.19 \\
\hline & & & & & $\mathrm{F}$ & 153 & 0.10 \\
\hline & & & & & $\mathrm{G}$ & 162 & 0.05 \\
\hline & & & & & $\mathrm{H}$ & 188 & 0.05 \\
\hline & & & & & I & 192 & 0.15 \\
\hline & & & & & $\mathrm{J}$ & 196 & 0.02 \\
\hline & & & & & $\mathrm{K}$ & 200 & 0.15 \\
\hline & & & & & $\mathrm{L}$ & 209 & 0.02 \\
\hline & & & & & M & 213 & 0.03 \\
\hline \multirow[t]{2}{*}{ CAUD020 } & 111-115 & 2 & 0.37 & 0.32 & $\mathrm{~A}$ & 111 & 0.28 \\
\hline & & & & & B & 115 & 0.72 \\
\hline CAUD021 & $184-184$ & 1 & 0.00 & 0.00 & A & 184 & 1.00 \\
\hline \multirow[t]{4}{*}{ CAUD022 } & $128-140$ & 4 & 0.57 & 0.62 & A & 128 & 0.40 \\
\hline & & & & & B & 133 & 0.05 \\
\hline & & & & & $\mathrm{C}$ & 137 & 0.23 \\
\hline & & & & & $\mathrm{D}$ & 140 & 0.32 \\
\hline \multirow[t]{4}{*}{ CAUD023 } & $163-183$ & 4 & 0.39 & 0.40 & A & 163 & 0.16 \\
\hline & & & & & B & 165 & 0.73 \\
\hline & & & & & $\mathrm{C}$ & 171 & 0.10 \\
\hline & & & & & $\mathrm{D}$ & 183 & 0.02 \\
\hline \multirow[t]{8}{*}{ CAUD024 } & $270-340$ & 13 & 0.93 & 0.88 & A & 270 & 0.16 \\
\hline & & & & & B & 278 & 0.07 \\
\hline & & & & & $\mathrm{C}$ & 281 & 0.02 \\
\hline & & & & & $\mathrm{D}$ & 284 & 0.02 \\
\hline & & & & & E & 288 & 0.05 \\
\hline & & & & & $\mathrm{F}$ & 292 & 0.14 \\
\hline & & & & & G & 296 & 0.16 \\
\hline & & & & & $\mathrm{H}$ & 300 & 0.09 \\
\hline
\end{tabular}


Table II. Continued.

\begin{tabular}{|c|c|c|c|c|c|c|c|}
\hline Locus & Fragment & Allele No. & Obs_Ht ${ }^{1}$ & $\mathrm{PIC}^{2}$ & Allele & size & Frequency \\
\hline \multirow[t]{5}{*}{ CAUD024 } & $270-340$ & 13 & 0.93 & 0.88 & I & 304 & 0.05 \\
\hline & & & & & $\mathrm{J}$ & 308 & 0.12 \\
\hline & & & & & $\mathrm{K}$ & 324 & 0.03 \\
\hline & & & & & $\mathrm{L}$ & 328 & 0.02 \\
\hline & & & & & $\mathrm{M}$ & 340 & 0.09 \\
\hline \multirow[t]{3}{*}{ CAUD025 } & 289-291 & 3 & 0.63 & 0.49 & $\mathrm{~A}$ & 289 & 0.37 \\
\hline & & & & & B & 290 & 0.10 \\
\hline & & & & & $\mathrm{C}$ & 291 & 0.53 \\
\hline \multirow{4}{*}{ CAUD026 } & $140-150$ & 4 & 0.70 & 0.67 & $\mathrm{~A}$ & 140 & 0.18 \\
\hline & & & & & $\mathrm{B}$ & 146 & 0.28 \\
\hline & & & & & $\mathrm{C}$ & 148 & 0.37 \\
\hline & & & & & $\mathrm{D}$ & 150 & 0.17 \\
\hline \multirow[t]{3}{*}{ CAUD027 } & 111-119 & 3 & 0.60 & 0.48 & $\mathrm{~A}$ & 111 & 0.55 \\
\hline & & & & & $\mathrm{B}$ & 115 & 0.35 \\
\hline & & & & & $\mathrm{C}$ & 119 & 0.10 \\
\hline CAUD028 & $143-143$ & 1 & 0.00 & 0.00 & $\mathrm{~A}$ & 143 & 1.00 \\
\hline \multirow[t]{2}{*}{ CAUD029 } & $112-114$ & 2 & 0.23 & 0.22 & $\mathrm{~A}$ & 112 & 0.85 \\
\hline & & & & & B & 114 & 0.15 \\
\hline \multirow[t]{2}{*}{ CAUD030 } & $257-261$ & 2 & 0.48 & 0.37 & $\mathrm{~A}$ & 257 & 0.53 \\
\hline & & & & & $\mathrm{B}$ & 261 & 0.47 \\
\hline \multirow[t]{4}{*}{ CAUD031 } & $112-126$ & 4 & 0.48 & 0.40 & $\mathrm{~A}$ & 112 & 0.62 \\
\hline & & & & & B & 114 & 0.02 \\
\hline & & & & & $\mathrm{C}$ & 118 & 0.02 \\
\hline & & & & & $\mathrm{D}$ & 126 & 0.34 \\
\hline \multirow[t]{3}{*}{ CAUD032 } & $115-121$ & 3 & 0.27 & 0.31 & $\mathrm{~A}$ & 115 & 0.18 \\
\hline & & & & & B & 117 & 0.78 \\
\hline & & & & & $\mathrm{C}$ & 121 & 0.03 \\
\hline \multirow[t]{4}{*}{ CAUD033 } & $200-206$ & 4 & 0.35 & 0.39 & $\mathrm{~A}$ & 200 & 0.74 \\
\hline & & & & & $\mathrm{B}$ & 202 & 0.10 \\
\hline & & & & & $\mathrm{C}$ & 204 & 0.13 \\
\hline & & & & & $\mathrm{D}$ & 206 & 0.03 \\
\hline \multirow[t]{2}{*}{ CAUD034 } & $215-217$ & 2 & 0.27 & 0.27 & $\mathrm{~A}$ & 215 & 0.80 \\
\hline & & & & & $\mathrm{B}$ & 217 & 0.20 \\
\hline \multirow[t]{4}{*}{ CAUD035 } & $223-237$ & 4 & 0.60 & 0.52 & $\mathrm{~A}$ & 223 & 0.13 \\
\hline & & & & & B & 231 & 0.23 \\
\hline & & & & & $\mathrm{C}$ & 233 & 0.60 \\
\hline & & & & & $\mathrm{D}$ & 237 & 0.05 \\
\hline
\end{tabular}

${ }^{1}$ Obs_Ht is the observed heterozygosity.

${ }^{2}$ PIC stands for the polymorphism information content.

monomorphic in three chicken breeds, and only one was polymorphic in three goose breeds (CAUD-G016). Sequencing results showed that the simple tandem repeat was present in both loci. For CAUD-C027, the flanking sequences and core repeats had high similarity (94\%) for the chicken and the duck, and for the chicken and the goose, but the number of repeats in the microsatellite 
in the duck was higher than that in the chicken. However, the similarity was moderate in the flanking sequences of CAUD-C016 and CAUD-G016, but a repeat unit found in the duck was absent in the chicken and the goose.

A total of 14 alleles were observed from 5 polymorphic microsatellite markers, which ranged from 2 to 3 with an average of 2.8 alleles per locus in the goose. In the other 9 loci only one allele was observed (see Tab. III). Sequencing results showed that the simple tandem repeat was contained in all 14 goose homologous loci (CAUD-G002, CAUD-G005, CAUD-G006, CAUD-G007，CAUD-G011，CAUD-G012，CAUD-G013，CAUD-G016, CAUD-G018，CAUD-G021，CAUD-G023，CAUD-G026，CAUD-G027, CAUD-G028) (see Tab. III). All of the flanking sequences were highly similar to the corresponding ones in the duck (90\%-98\%), but a bit different for CAUD-G005 (83\%). The variance in the core sequence was higher than that in the flanking sequence. For CAUD-G002, CAUD-G005, CAUD-G011, CAUD-G013，CAUD-G018，CAUD-G021，CAUD-G023，CAUD-G026, CAUD-G027, and CAUD-G028, the core sequences in the goose were shorter than those in the duck. Conversely, the core sequence in CAUD-G007 and CAUD-G012 in the goose was longer than that in the duck. Moreover, part of the repeat unit found in the duck was absent in the goose at CAUD-G016 and CAUD006.

Sequences of 2 chicken and 14 goose microsatellite loci were submitted to GenBank (AY866384-AY866399).

\section{DISCUSSION}

\subsection{Evaluation of the microsatellite markers}

Although the repeat number in the 35 microsatellite markers was high (18.28/sequence), $20 \%$ of the markers had only one allele in the genotyped population. The main reason was that the population we examined had been selected for several generations. These markers may show polymorphism if more individuals or more populations or breeds are analyzed. Five out of 28 polymorphic microsatellite markers had a PIC lower than 0.25 , and only 9 loci were informative.

\subsection{Evaluation of cross-species amplification}

This study was the first attempt to detect a duck-specific primer in pheasant birds. The results indicate only $5.7 \%$ of the primers designed for the duck could be useful in the analysis of the chicken genome, and none of them could be 


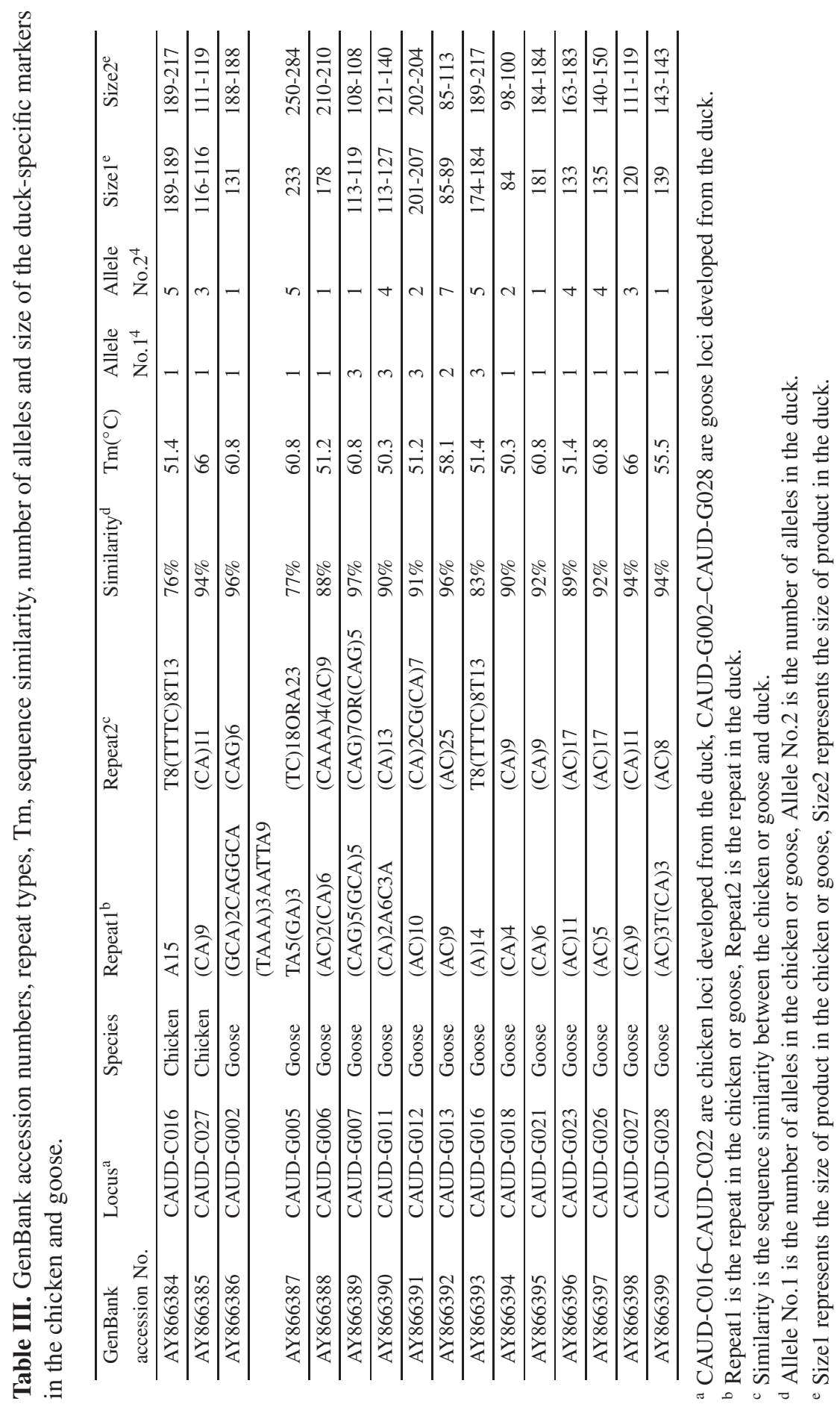


useful in the analysis of the peacock genome. In contrast to the pheasant bird, $40 \%$ of the 35 duck primers yielded specific PCR products. The difference in the success rates could be attributed to the relationship among the four birds. Both the chicken and peacock belong to the order Galliformes, but the duck and goose belong to the order Anseriformes. There should be high variance in the flanking sequence of the microsatellite between the two orders. The results showed that it was difficult to screen the microsatellite marker for the duck by cross-species amplification from chicken loci. But it was possible to isolate a marker from the same order. The success rates of the heterologous amplification with microsatellite primers in closely related species ranged from $16.23 \%$ to $62.89 \%[1,9,17-19,25,31]$. Besides the above factor, difference in stringency used for amplification could also be attributed to this result [27].

Although the numbers of alleles ranged from 3 to 5 with an average of 4 at CAUD016 and CAUD027 in the Peking duck, there was only one allele in three chicken breeds. Five of 14 markers were polymorphic in the genotyped goose, with an average of 2.8 per locus. The number of alleles at all common loci in the chicken or goose was less or equal to that of the duck except CAUD-G007 and CAUD-G012. There are two possible reasons for this result. One is that the mutational rate in the core sequence at the loci in the chicken or goose is lower than in the original species (duck). The other is that the population used in the study was small, and therefore the effect of random variation is less acute.

With regards to the product size in cross-species amplification, the results were inconsistent in the different taxa $[1,9,38]$. In this study, only one locus (CAUD-G007) in the goose was larger than that in the duck, seven loci in the chicken or goose were equivalent to that in the duck, and nine loci in the goose were smaller than that in the duck. In addition, the size of one homologous locus in the chicken (CAUD-C016) was larger than that in the goose (CAUD-G016). The size of the other homologous loci was the same in the two birds.

Based on sequence comparisons of the flanking sequence and repeat, we conclude that 2 chicken loci and 14 (see Tab. III) goose loci are true homologous loci of the duck loci from which the markers were developed. These loci should be useful for comparative mapping among the birds.

Although microsatellites are informative and powerful genetic markers, only 102 microsatellite markers specific for waterfowl were preciously reported $[3,23,24,29,35]$. The goal of the present study was to isolate novel microsatellite markers in the duck by an enriched library. The majority of loci developed in this study are polymorphic in our population. These loci will be 
useful for linkage and QTL mapping, population genetics and phylogenetic studies. In addition, the novel goose microsatellite loci developed by crossspecies are useful for population genetic study and linkage mapping.

\section{ACKNOWLEDGEMENTS}

We sincerely thank S.Q. Hu and J.P. Hao (Gold Star Duck Production Ltd, Peking) for collecting duck blood samples. We are grateful to Z.Q. Du and Y. Gao for suggestion of the data analysis. The authors also acknowledge Jamie Wilson (Human Molecular Genetics Group, Department of Pathology, Tennis Court Rd, Cambridge) for comments on the manuscript. This research was funded by a grant from the State Major Basic Research Development Program of China (G20000161).

\section{REFERENCES}

[1] Baratti M., Alberti A., Groenen M., Veenendaal T., Fulgheri F.D., Polymorphic microsatellites developed by cross-species amplification in common pheasant breeds, Anim. Genet. 32 (2001) 222-225.

[2] Bochno R., Rymkiewicz J., Szeremeta J., Regression equations for in vivo estimation of the meat content of Pekin duck carcass, Br. Poultry Sci. 41 (2000) 313-317.

[3] Buchlolz W.G., Pearce J.M., Pierson B.J., Scribner K.T., Dinucleotide repeat polymorphisms in waterfowl (family Anatidae): characterization of a sex-linked (Z-specific) and 14 autosomal loci, Anim. Genet. 29 (1998) 323-325.

[4] Chakraborty R., Kimmer M., Stivers D.N., Davison L.J., Deka R., Relative mutation rates at di-, tri-, and tetranucleotide microsatellite loci, Proc. Natl. Acad. Sci. USA 94 (1997) 1041-1046.

[5] Chowdhury S., Bansal M., Modelling studies on neurodegenerative diseasecausing triplet repeat sequences d(GGC/GCC)n and d(CAG/CTG)n, J. Biosci. 26 (2001) 649-665.

[6] Cooper A., Rhymer J., James H.F., Ancient DNA and island endemics, Nature 381 (1996) 484

[7] Crittenden L.B., Provencher L., Levin I., Abplanalp H., Briles R.W., Dodgson J.B., Characterization of a Red Jungle Fowl by White Leghorn backcross reference population for molecular mapping of the chicken genome, Poultry Sci. 72 (1993) 334-348.

[8] Donne-Gousse C., Laudet V., Hänni C., A molecular phylogeny of anseriformes based on mitochondrial DNA analysis, Mol. Phylogenet. Evol. 23 (2002) 339-356.

[9] Fields R.L., Scribner K.T., Isolation and characterization of novel waterfowl microsatellite loci: cross-species comparisons and research applications, Mol. Ecol. 6 (1997) 199-202. 
[10] Fischer D., Bachmann K., Microsatellite enrichment in organisms with large genomes, BioTechniques 24 (1998) 796-802.

[11] Hatta M., Halfmann P., Wells K., Kawaoka Y., Human influenza a viral genes responsible for the restriction of its replication in duck intestine, Virol. 295 (2002) 250-255.

[12] Hu Y.H., Poivey J.P., Rouvier R., Wang C.T., Tai C., Heritabilities and genetic correlations of body weights and feather length in growing Muscovy selected in Taiwain, Br. Poultry Sci. 40 (1999) 605-612.

[13] Jernej J., Branka J., High throughput isolation of microsatellites in Hop (Humulus lupulus L.), Plant Mol. Report. 19 (2001) 217-226.

[14] Johnson K.P., Sorenson M.D., Comparing molecular evolution in two mitochondrial protein coding genes (cytochrome $b$ and ND2) in the dabbling ducks (Tribe: Anatini), Mol. Phylogenet. Evol. 10 (1998) 82-94.

[15] Johnson K.P., Sorenson M.D., Phylogeny and biogeography of dabbling ducks (Genus: Anas): a comparison of molecular and morphological evidence, The Auk 116 (1999) 792-805.

[16] Kandpal R.P., Kandpal G., Weissman S.M., Construction of libraries enriched for sequence repeats and jumping clones, and hybridization selection for regionspecific markers, Proc. Natl. Acad. Sci. USA 91 (1994) 88-92.

[17] Kayang B.B., Inoue-Murayama M., Hoshi T., Matsuo K., Takahashi H., Minezawa M., Mizutani M., Ito S., Microsatellite loci in Japanese quail and cross-species amplication in chicken and guinea fowl, Genet. Sel. Evol. 34 (2002) 233-253.

[18] Kemp S.J., Hishida O., Wambugu J., Rink A., Longeri M.L., Ma R.Z., Da Y., Lewin H.A., Barendse W., Teale A.J., A panel of polymorphic bovine, ovine and caprine microsatellite markers, Anim. Genet. 26 (1995) 299-306.

[19] Kim K.S., Min M.S., An J.H., Lee H., Cross-species amplification of bovidae microsatellites and low diversity of the endangered Korean goral, J. Hered. 95 (2004) 521-525.

[20] Li K.S., Xu K.M., Peiris J.S., Poon L.L., Yu K.Z., Yuen K.Y., Shortridge K.F., Webster R.G., Guan Y., Characterization of H9 subtype influenza viruses from the ducks of southern China: a candidate for the next influenza pandemic in humans?, J. Virol. 77 (2003) 6988-6994.

[21] Lin Y.P., Shaw M., Greory V., Cameron K., Lim W., Klimov A., Subbarao K., Guan Y., Krauss S., Shortridge K., Webster R., Cox N., Hay A., Avian-to-human transmission of H9N2 subtype influenza a viruses: Relationship between H9N2 AND H5N1 human isolates, Proc. Natl. Acad. Sci. USA 97 (2000) 9654-9658.

[22] Liu H.T., Hu Y.H., Wang C.T., Lin L.Y., Sequences and comparisons of duck mitochondrial DNA control regions, Comp. Biochem. Physiol. 115B (1996) 209-214.

[23] Maak S., Neumann K., Lengerken G.V., Gattermann R., First seven microsatellites developed for the Peking duck (Anas platyrhynchos), Anim. Genet. 31 (2000) 228-241.

[24] Maak S., Wimmers K., Weigend S., Neumann K., Isolation and characterization of 18 microsatellites in the Peking duck (Anas platyrhynchos) and their application in other waterfowl species, Mol. Ecol. Notes 3 (2003) 224-227. 
[25] Moore S.S., Sargeant L.L., King T.L., Mattick J.S., Georges M., Hetzel D.J.S., The conservation of dinucleotide microsatellites among mammalian genomes allows the use of heterologous PCR primer pairs in closely related species, Genomics 10 (1991) 654-660.

[26] Olson S.L., The fossil records of birds, in: Farner D.S., King J.R., Parkes K.C. (Eds.), Avian Biology, Academic Press, New York, 1985, pp. 79-238.

[27] Pang S.W.Y., Ritland C., Carlson J.E., Cheng K.M., Japanese quail microsatellite loci amplified with chicken-specific primers, Anim. Genet. 30 (1999) 195-199.

[28] Paniego N., Echaide M., Munoz M., Fernandez L., Torales S., Paula F., Fuxan I., Carrera M., Zandomeni R., Suarez E.Y., Hopp H.E., Microsatellite isolation and characterization in sunflower (Helianthus annuus L.), Genome 45 (2002) 34-43.

[29] Paulus K.B., Tiedemann R., Ten polymorphic autosomal microsatellite loci for Eider duck Somateria mollissima and their cross-species applicability among waterfowl species (Anatidae), Mol. Ecol. Notes 3 (2003) 250-252.

[30] Rassmann K., Schlotterer C., Tauz D., Isolation of simple sequence loci for use in polymerase chain reaction-based DNA fingerprinting, Electrophoresis 12 (1991) 113-118.

[31] Reed K.M., Mendoza K.M., Beattie C.W., Comparative analysis of microsatellite loci in chicken and turkey, Genome 43 (2000) 796-802.

[32] Reed K.M., Chaves L.D., Garbes J.R., Da Y., Harry D.E., Allelic variation and genetic linkage of avian microsatellites in a new turkey population for genetic mapping, Cytogenet. Genome Res. 102 (2003) 331-339.

[33] Rouvier R., Guy G., Paillet D.R., Poujardieu B., Genetic parameters from factorial cross breeding in two duck strains (Anas Platyrhynchos) Brown Tsaiya and Pekin, for growth and fatty liver traits, Br. Poultry Sci. 35 (1994) 509-517.

[34] Sraml M., Christidis L., Easteal S., Horn P., Collet C., Molecular relationships within Australian waterfowl (Anseriformes), Aust. J. Zool. 45 (1996) 47-58.

[35] Stai S.M., Hughes C.R., Characterization of microsatellite loci in wild and domestic Muscovy ducks (Cairina moschata), Anim. Genet. 34 (2003) 387-389.

[36] Takashi I., Cassandra L., Charles R.C., Sequence-specific DNA purification by triplex affinity capture, Proc. Natl. Acad. Sci. USA 89 (1992) 495-498.

[37] Tang B., Huang Y.H., Lin L., Hu X.X., Feng J.D., Yao P., Zhang L., Li N., Isolation and characterization of 70 novel microsatellite markers from ostrich (Struthio camelus) genome, Genome 46 (2003) 833-840.

[38] Van Hooft W.F., Hanotte O., Wenink P.W., Groen A.F., Sugimoto Y., Prins H.H.T., Teale A., Applicability of bovine microsatellite markers for population genetic studies on African buffalo (Syncerus caffer), Anim. Genet. 30 (1999) 214-220.

[39] Velez A., Brun J.M., Rouvier R., Crossbreeding effects on reproductive traits in two strains of duck (Anas platyrhynchos): Brown Tsaiya and Pekin, Br. Poultry Sci. 37 (1996) 571-577. 